\title{
BIOLOGY
}

\section{Gonadal development and fecundity of the smooth weakfish Cynoscion leiarchus (Teleostei: Perciformes: Sciaenidae) in a tropical Brazilian bay}

\author{
José P. do Carmo Silva ${ }^{1}$, Marcus R. da Costa ${ }^{1,2}$, Iracema D. Gomes ${ }^{1} \&$ Francisco G. Araújo $^{1^{*}}$
}

'Laboratório de Ecologia de Peixes, Departamento de Biologia Animal, Universidade Federal Rural do Rio de Janeiro. Rodovia BR 465, km 7, 23897-000 Seropédica, RJ, Brazil.

${ }^{2}$ Laboratório de Ecopesca, Departamento de Biologia Marinha, Universidade Federal Fluminense. Rua Outeiros de São João Batista, Campus Valonguinho, Centro, 24210-130 Niterói, RJ, Brazil.

*Corresponding author. E-mail: gersonufrrj@gmail.com

\begin{abstract}
Cynoscion leiarchus (Cuvier, 1830) is a coastal fish species that is widely distributed along the Western Atlantic coast, from Belize to Southern Brazil. In Brazil, C. leiarchus It is an important resource for commercial and artisanal fisheries. Our objective was to describe the oogenesis and spermatogenesis stages of the species and to estimate batch size and relative fecundity of a population at a tropical bay in southeastern Brazil. The examined specimens were obtained from artisanal catches that took place from July 2013 to June 2014. A total of 18 individuals (11 females and 7 males) were examined for histological analysis and 20 spawning-capable females were used to estimate fecundity. Five stages of oocyte development (primary growth, pre-vitellogenic, vitellogenic, oocyte maturation and atresia) and four stages of spermatocytes (spermatogonia, spermatocytes, spermatids, spermatozoa) were described in different phases of gonad development (immature, developing, spawning capable and regenerating), suggesting that spawning happens in batches, oocyte development is asynchronic and fecundity is indeterminate. Batch fecundity ranged from $100 \times 10^{3}$ to $866 \times 10^{3}$ oocytes undergoing final oocyte maturation, and relative fecundity ranged from 232 to 1,225 oocytes, averaging 467 oocytes per gram of ovary-free body weight. Fecundity tended to increase linearly with gonadal weight, total weight, total length, and age, but the highest linear correlation obtained was between fecundity and gonadal weight. This study provides the first information on the gonadal development of $C$. leiarchus from the Brazilian coast and is a baseline to compare with other populations and/or congeneric species.
\end{abstract}

KEY WORDS. Histology, oocyte, reproductive tactics, Sepetiba Bay.

The assessment of the stages of gonadal development of fish species is an important issue in many studies of fish reproductive biology. Fish exhibit different strategies and tactics that maximize reproductively active offspring in relation to the available energy (Wootton 1984, Roof 1992, Brown-Peterson et al. 2011). These strategies have been assessed based mainly on the knowledge of germ cell lineage development and fecundity, which are essential to understand the maturation process and oocyte recruitment patterns (MURUA \& SABORIDO-REy 2003, CosTA et al. 2015). Bioimaging the dynamic processes of germ cell development of fish species is uniquely easy. Oogenesis is a very dynamic process in the ovaries. During it, the oocyte passes through various phases of development that are very similar among different fish species (Selman \& Wallace 1989). For instance, staging based on the external appearance of the ovary is the simplest and most rapid method to assess the ovarian de- velopment phases. Moreover, oocyte size may be used to predict the developmental stage of the embryo when the size ranges of the various stages are known and do not overlap. When they overlap, however, histological techniques are a more accurate method of estimating the developmental stages and phases of the germinative cells.

Fecundity is another important aspect of fish reproductive biology (Lowerre-BARBIERI 2009). Knowledge of the fecundity of a species is important to fish stock management. It is used to calculate the reproductive potential of a stock, and enhances our ability to estimate recruitment. For this reason, information on fecundity is very important for estimating individual reproductive potential, evaluating the productivity of the population, and characterizing specific populations (LAMBert et al. 2003, Armstrong \& Witthames 2012, Costa et al. 2016). Therefore, to understand the reproductive strategies in fishes, it is important 
to understand oocyte development, ovarian organization, and fecundity (Murua \& Saborido-Rey 2003, Costa et al. 2015).

The smooth weakfish Cynoscion leiarchus (Cuvier, 1830) is a coastal fish species distributed along the Western Atlantic coast, from Belize to Southern Brazil. This species is usually found on mud and sand bottoms in estuarine areas, and along the coastline down to about $60 \mathrm{~m}$ depth (Menezes \& Figueiredo 1980). It is an important resource for commercial and artisanal fisheries in Brazil. Records of catches of this fish are available between 2008 to 2010, of 910, 1003 and 948 t year $^{-1}$, respectively (MPA 2012). In the Southeast region, for example, the total landings of this species in 2006 were $325.5 \mathrm{t}$, of which approximately $38 \%$ were in the state of Rio de Janeiro (IBAMA 2008). In the Sepetiba Bay $\left(22^{\circ} 54^{\prime}-23^{\circ} 04^{\prime} \mathrm{S}, 43^{\circ} 34^{\prime}, 44^{\circ} 10^{\prime} \mathrm{W}\right)$, a $450 \mathrm{~km}^{2}$ embayment in the Southeastern coast of Rio de Janeiro, this species ranks among the most abundant fish species, occurring mainly in the outer bay zone (ArAújo et al. 2006) that has predominantly polyhaline waters (salinity average $=30$ ), and mean temperature ranging between $21.5^{\circ} \mathrm{C}$ (winter) and $27^{\circ} \mathrm{C}$ (summer) (ArAújo et al. 2002). Despite the wide geographical distribution and commercial value of $C$. leiarchus, information on the reproductive biology of the species is still lacking.

The reproductive strategies and tactics of other species of Cynoscion along the Atlantic coast of the United States, Gulf of Mexico, Mexico and South America have been studied. Such studies reported an extended reproductive season, multiple spawning, asynchronous oocyte development and indeterminate fecundity for Cynoscion nebulosus (Cuvier, 1830) in southern Texas and coast of Mississippi (Brown-Peterson et al. 1988, Brown-Peterson \& WARren 2001) and for Cynoscion othonopterus (Jordan \& Gilbert, 1882) in the Colorado River Delta, Mexico (Gherard et al. 2013). Brown-Peterson et al. (2002), studying C. nebulosus in five estuaries from Charlotte Harbor to Redfish Bay, USA, observed subtle but consistent differences in batch fecundity among the estuaries. TAYLOR \& VILLOSO (1994) described aspects of the daily ovarian cycle and spawning of Cynoscion regalis (Bloch \& Schneider, 1801) in the Delaware Bay (USA) and found that this species has batch fecundity, with spawning at irregular intervals during the early hours of the evening. In South America, MarCano \& Alió (2001) reported a wide range of diameters of mature oocytes, indicating multiple spawning for Cynoscion jamaicensis (Vaillant \& Bocourt, 1883) in the northern coast of Paria Peninsula, Venezuela. In Brazil, VIeIRA \& HaimovicI (1997) studying the oocyte development and batch fecundity of C. guatucupa (Cuvier, 1830) (synonymous of C. striatus), reported consistent similar reproductive patterns for this species from Southern Brazil to Argentina. Militeld \& MaCchi (2006) also estimated batch fecundity for C. guatucupa in the coastal waters of Argentina-Uruguay.

The objective of this study was to describe for the first time aspects of the reproductive strategy of C. leiarchus in the Sepetiba Bay: (i) to describe the stages of development of germinative cells, (ii) to determine oocyte size frequency distribution and (iii) to assess batch fecundity. We expected to find oocytes overlapping in different stages at individual level, suggesting multiple spawning and batch fecundity for this species, a general characteristic within Cynoscion. We also compare our results with another species within the family Sciaenidae, to test whether closely related species exhibit similar reproductive strategies to avoid interspecific competition among offspring.

\section{MATERIAL AND METHODS}

We collected specimens from artisanal catches from July 2013 to June 2014 . The nets were $1,500 \mathrm{~m}$ long, $3 \mathrm{~m}$ in depth, and had three panels of different mesh sizes $(35,45$, and $35 \mathrm{~mm}$ adjacent mesh). All fish specimens were stored in ice and transported to the laboratory, where they were measured (total length) (TL, nearest $1 \mathrm{~mm}$ ) and weighted (TW, nearest $0.01 \mathrm{~g}$ ). A ventral incision was made to expose gonads for sex determination and the development stage of the macroscopic gonad. Gonads were removed and weighed while wet $\left(\mathrm{W}_{\mathrm{G}}\right.$, nearest $\left.0.01 \mathrm{~g}\right)$. Voucher specimens were deposited in the ichthyological collection of the Laboratório de Ecologia de Peixes of the Universidade Federal Rural do Rio de Janeiro under number: LEP-UFRRJ\#1600.

A subsample of 18 specimens (11 females and 7 males) was examined for histological analysis. The female subsample

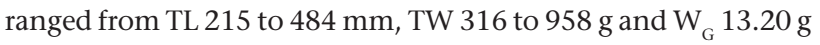
to $64.80 \mathrm{~g}$. Males ranged from 290 to $493 \mathrm{~mm}$ TL, TW 194 to $1269 \mathrm{~g}$ and $\mathrm{W}_{\mathrm{G}} 0.10$ to $4.00 \mathrm{~g}$. A portion $(<0.05 \mathrm{~g})$ of each ovary and testis were taken from the middle part of the gonad, being weighed to the nearest $0.01 \mathrm{mg}$ and fixed in Bouin's solution for histological study during 12 hours, being then transferred to $70 \%$ ethanol for preservation. Afterwards, the gonads were dehydrated and embedded in paraffin wax. Cross-sections, 4-6 $\mu \mathrm{m}$ thick, were made in a rotary microtome (Leica RM 2135, Wetzlar, Germany), stained with haematoxylin eosin (HE) and mounted on glass slides for light microscopy scrutiny (SPECTOR \& GOLDMAN 2006). Microphotographs were taken with a MOTICAM 23003.0 megapixels camera coupled to an Olympus BX41 microscope.

Identification of the gonadal maturation phases and oocyte development stages were made following the criteria in Brown-Peterson et al. (2011) for histological analyses. Primary growth oocytes were determined based on the occurrence of oogonia, chromatin nucleolar and perinucleolar stages. Accordingly, all vitellogenic oocytes and cortical alveolar oocytes are secondary growth oocytes. Vitellogenesis is normally a long process during which important and visible changes occur within the oocyte: oocyte size increases noticeably, yolk progressively accumulates in the cytoplasm and several cytoplasmatic inclusions appear (vacuoles, yolk globules, etc.). In this study, vitellogenic oocytes are separated into three stages (primary (Vtg1), secondary (Vtg2) and tertiary (Vtg3) based on the diameter of the oocyte, the amount of cytoplasm filled with yolk globules, and appearance of the zona radiata. The Vtg3 oocyte has the necessary receptors for the maturation-inducing hormone and thus 
is able to progress to oocyte maturation (OM) (BRown-PeTERSON et al. 2011). Oocyte maturation is divided into four stages based on cytoplasmic and nuclear events, beginning with germinal vesicle migration (GVM) and ending with hydration (JALABER 2005); ovulation is not considered a part of OM.

For each fish, the diameter of the oocytes and their nucleus were measured to the nearest $0.1 \mu$ using the Image J software and the mean diameter of each type of oocyte was then calculated. Measurements were taken on oocytes sectioned through the nucleus. The spermatogenic stages follow those outlined by GRIER \& Uribe-Aranzábal (2009) and include the stages spermatogonia (Sg), spermatocytes (Sc), spermatids (St), and spermatozoa (Sz), which can be differentiated by a decrease in size and an increase in basophilic staining as development progresses from Sg to Sz.

Batch fecundity was estimated by direct counts of oocytes undergoing $\mathrm{OM}(>400 \mu \mathrm{m})$ in subsamples of 20 ovaries with intense yellow color in final maturation of the spawning capable phase, and calculated as: $\mathrm{F}=\mathrm{N} \times \mathrm{W}_{\mathrm{G}} \times \mathrm{W}_{\mathrm{GS}^{-1}}$, where $\mathrm{F}=$ fecundity, $\mathrm{N}=$ number, $\mathrm{W}_{\mathrm{G}}$ = total gonad weight and $\mathrm{W}_{\mathrm{GS}}=$ gonadal subsample weight. This criteria is in agreement with the statement of Hunter \& MACEWICZ's (1985) that oocytes undergoing final oocyte maturation may be included as hydrated oocytes when hydration occurs very rapidly. Relative fecundity (number of eggs per gram of ovary-free body weight) was calculated to remove the effect of body size. A linear regression analysis was performed to assess relationships between fecundity with total length, total body weight, gonad weight and age. The age data were obtained from SiLva (2015), who used otoliths for determining age in this species.

\section{RESULTS}

\section{Stages of oocyte development}

Primary Growth - PG (Figs. 1-2): Oogonia, chromatin nucleolar and perinucleolar stages are present in the ovary throughout the entire annual cycle, and are referred to as primary growth oocytes (diameter $<30 \mu \mathrm{m}$ ). Oocyte diameter averaged $28.14 \pm 0.50 \mu \mathrm{m}(\mathrm{n}=60)$ and nucleus $12.64 \pm 0.30 \mu \mathrm{m}(\mathrm{n}=60)$. We observed this stage in in all phases of ovarian development.

Pre-vitellogenic (Figs. 3-4): Cortical alveoli formation: oocytes in different stages of development. Small vesicles and alveoli appear in the periphery of the cytoplasm. Mean diameter of oocyte $55.38 \pm 2.85 \mu \mathrm{m}(\mathrm{n}=60)$ and nucleus $15.92 \pm 1.43$ $\mu \mathrm{m}(\mathrm{n}=60)$. Zona radiata visible, although not yet stained by eosin. Accumulation of lipid inclusions in cytoplasm has begun. Cortical alveoli were observed in in developing and spawning capable phases.

Vitellogenic (Fig. 3-4): Primary vitellogenic (Vtg1). In early stage, yolk granules small and numerous, also called yolk spheres or yolk globules, containing cortical alveoli, occupying the entire cytoplasm. Mean oocyte diameter 76.07 $\pm 5.52 \mu \mathrm{m}$ ( $\mathrm{n}=$ $60)$ and nucleus $24.79 \pm 1.99 \mu \mathrm{m}(\mathrm{n}=60)$; secondary vitellogenic (Vtg2). Cortical alveoli increase in size and gravitate towards the periphery as the yolk granules grow. Follicular layer and zona radiata are visible, with the latter being dyed with eosin. Mean oocyte diameter $164.60 \pm 6.09 \mu \mathrm{m}(\mathrm{n}=60)$ and nucleus $54.07 \pm 3.40 \mu \mathrm{m}(\mathrm{n}=60)$; Tertiary vitellogenic (Vtg3). Lipid inclusions dispersed in the cytoplasm. Mean oocyte diameter $293.03 \pm 10.23 \mu \mathrm{m}(\mathrm{n}=60)$ and nucleus $69.40 \pm 3.36 \mu \mathrm{m}(\mathrm{n}=$ 60). Primary and secondary vitellogenic oocytes were present in the developing ovarian phase and all stages of vitellogenic are present in spawning capable ovarian phase.

Oocyte maturation (Fig. 4): Oocytes in early and late stages were observed. The following characteristics of oocyte maturation $(\mathrm{OM})$ were noted: germinal vesicle migration (GMV), germinal vesicle breakdown (GVDB), yolk coalescence or clarification (JALABERT 2005). Early OM included GVM, but little yolk coalescence. Late OM was characterized by completed GVM or GVBD, yolk coalescence. Mean oocyte diameter 397.61 \pm 7.13 . Oocytes in final maturation stage represent the actively spawning subphase of the spawning capable ovarian phase.

Atresia (Fig. 2-3): Atretic oocytes were detected and characterized by disintegration of the nucleus and evident irregular shape as into alpha stage. The cells of the granular layer migrate to the interior of the ooplasm, absorbing the yolk; at the end of this stage the zona radiata disappears. Although thus stage could occur in any phase, except immature and actively spawning sub-phase, we only observed atresia stage in regenerating and spawning capable phases.

\section{Stages of spermatocytes development}

The spermatogenic cells appear in the interior of lobules at different stages during spermatogenesis (spermatogonia (Sg), spermatocytes (Sc), spermatids (St) and spermatozoa (Sz)), forming cysts (Cy). Each cyst is bound by a layer of connective tissue and contains cells at the same stage of development. In spawning capable testes, the lobules are filled with spermatozoa, continuo germinal epithelium at testis periphery (Figs. 5-6).

\section{Oocyte size distribution}

The size-frequency distribution of oocytes differed for each phase of gonadal maturation (Fig. 7). Oocytes in the reserve stock had diameter $<25 \mu \mathrm{m}$ and were present in large numbers in all maturation phases; the immature phase showed in second class oocytes ranging from 26 to $36 \mu \mathrm{m}$ in diameter In the developing phase, a continuum oocyte distribution with diameter of oocytes ranging from 20 to $299 \mu \mathrm{m}$ was observed. The spawning capable showed the same pattern with diameter of oocytes ranging from 250 to $407 \mu \mathrm{m}$. The regenerating phase oocyte distribution was similar to the immature phase, with diameter ranging from 20-42 $\mu \mathrm{m}$.

\section{Fecundity}

Batch fecundity ranged from $100 \times 10^{3}$ to $866 \times 10^{3}$ oocytes undergoing $\mathrm{OM}$. The relative fecundity ranged from 232 to 1,225 oocytes, averaging $467 \pm 48$ oocytes per gram of somatic body weight (ovary-free). We counted approximately 

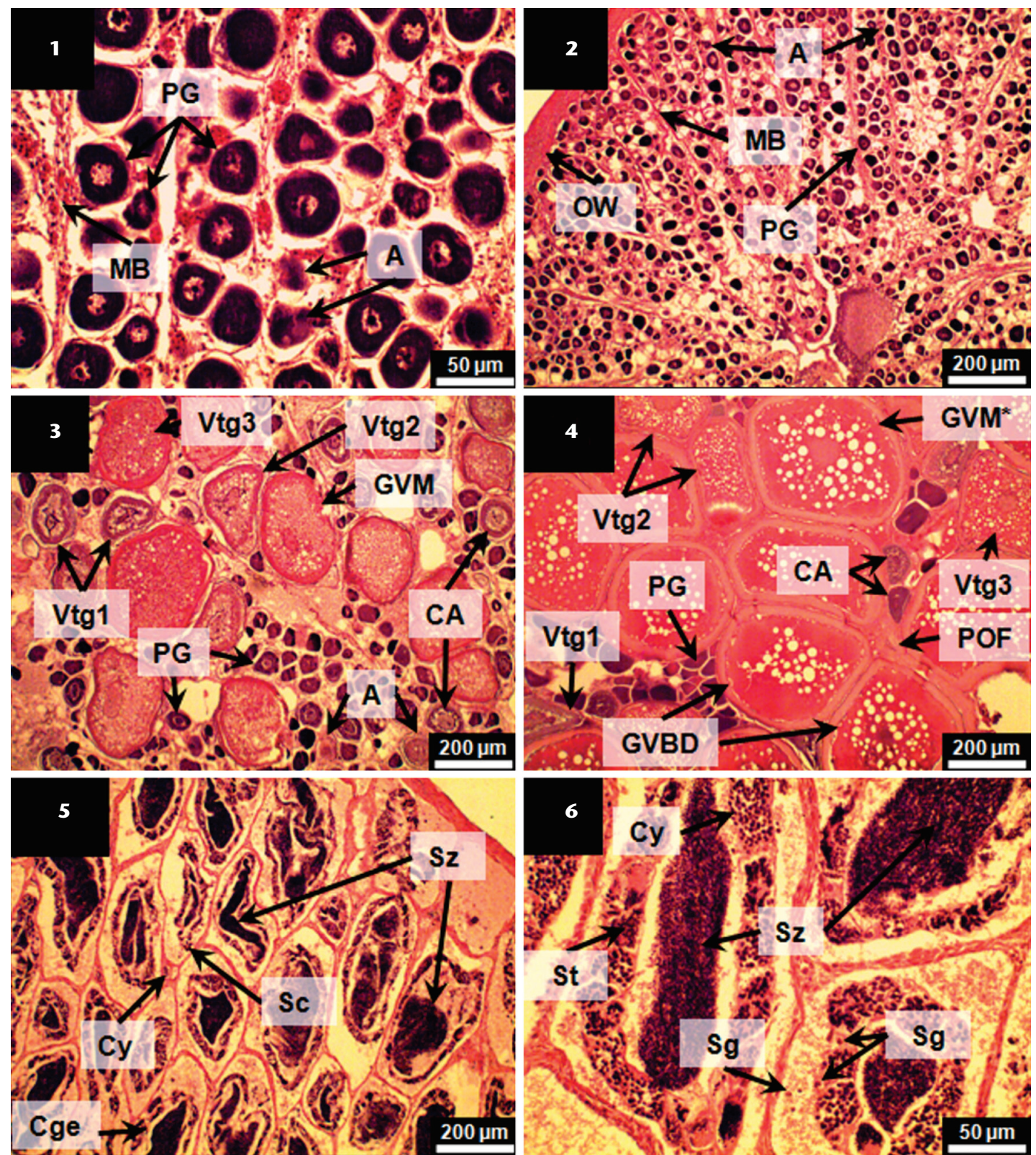

Figures 1-6. Photomicrographs of ovarian (1-4) and testicular (5-6) histology illustrating oocytes and spermatocytes at different development stages of C. leiarchus: (1-2) regenerating ovarian phase; (3) spawning capable ovarian phase; (4) actively spawning subphase; (56) spawning capable testis phase. (PG) Primary growth, (MB) muscle bundle, (CA) cortical alveolar, (OW) ovarian wall, (Vtg1) primary vitellogenic, (Vtg2) secondary vitellogenic, (Vtg3) tertiary vitellogenic, (A) atresia POF: postovulatory follicle complex, (GVM) germinal vesicula migration, (GVBD) germinal vesicular breackdown, (Sg1) primary spermatogonia, (Sz) spermatozoa, (Cy) spermatocyst.

220 oocytes for each of the 20 examined females, with a total of 4,500 measured oocytes. Fecundity tended to increase linearly with gonad mass, total mass, total length, and age $(\mathrm{p}<0.05)$ with the highest linear correlation $(r=0.82)$ obtained between the gonad weight and fecundity (Fig. 8-11).

\section{DISCUSSION}

Histological analyses allowed the detection and description of changes in five oogenesis and four spermatogenesis stages of Cynoscion leiarchus from Sepetiba Bay. This species seems to 


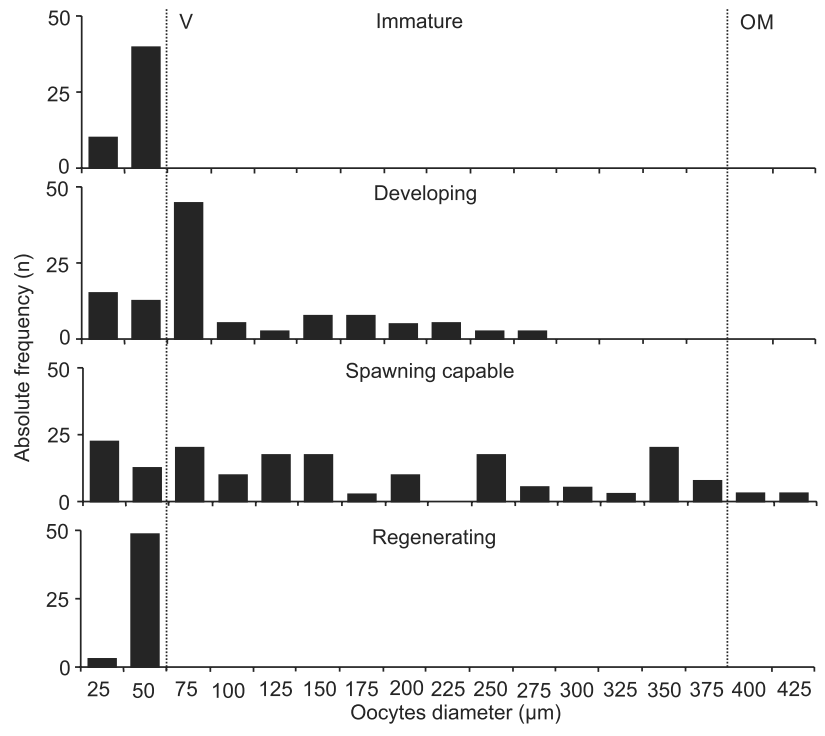

Figure 7. Oocyte size-frequency distribution through subsequent phases of gonad development of Cynoscion leiarchus. Dashed line (V) indicate early vitellogenesis and (OM) indicate early oocyte maturation.

spawn in batches, with asynchronic oocyte development and indeterminate fecundity, suggesting a long spawning season. According to Winemiller \& LAYMAN (2005), this type of behavior may be considered an adaptive response to environmental variations. This involves allocation of energy for different stages of life in order to ensure the survival of recruits and juveniles, as a result of a large investment of the parents to produce a high number of offspring at each reproductive cycle (PIANKA 1970), even if each individual has little chance of surviving to adult age.

According to FonTeLes-FilHo (2011), batch spawning is common in tropical areas, and reflects adaptation to environmental constraints to optimize release of gametes in a synchronized process related with food availability for larvae and post larvae. This ensures a greater survival of the offspring. This reproductive pattern was also observed in other species of Cynoscion, for instance C. nebulosus from the Golf coast of Mississipi (Brown-PETERSON \& WARREN 2001) and from the South Carolina (Roumillat \& Brouwer 2004), C. othonopterus from the California Gulf (GHERARD et al. 2013), C. jamaicensis from Venezuela coast (Marcano \& Alió 2001), C. guatucupa from Southern Brazil (VieIRA \& HaImovicI 1997) and Argentinian-Uruguaian coast (Militelli \& MACCHI 2006), thus confirming that batch spawning and indeterminate fecundity are common strategies in Cynoscion. These reproductive traits were also observed in other Sciaenidae species, for instance Macrodon ancylodon (Bloch \& Schneider, 1801) (JURAs \& YAMAGUTI 1989), Menticirrhus americanus (Linnaeus, 1758) (CHAVEs 1989), Isopisthus parvipinnis (Cuvier, 1830) (CHAves 1989), Stellifer rastrifer (Jordan, 1889) (Chaves \& Vendel 1997), Paralonchurus brasiliensis (Steindachner, 1875) (CosTA et al. 2015). Thus, these patterns confirm that closely related species develop strategies to avoid interespecific competition for limited resources and to overcome environmental constrains (WOOTTON 1992, AMARASEKARE 2003). For instance, timing segregation in reproduction will enable offspring to maximize the use of the available resources, facilitating survival and reproductive success. We therefore consider that this trait is common to the entire family.

The analysis of oocyte size-frequency distributions in the developing and spawning capable phases reveals continuous oocyte recruitment into vitellogenesis. Batch spawners with these features exhibit asynchronous oocyte development and indeterminate fecundity, characterized by the presence of oocytes in several developmental stages in the ovary during the developing phase Brown-PETERSON et al. (2011) and by the permanence of this oocyte recruitment during the spawning season, making it impossible to estimate fecundity with precision (WALLACE \& Selman 1981, Hunter et al. 1992, Gordo et al. 2008). Therefore, this pattern corroborates $C$. leiarchus as a batch spawner with asynchonic oocyte development and indeterminate fecundity. Furthermore, batch-spawning species with indeterminate fecundity will have different oocyte developmental patterns depending on how quickly the oocytes are recruited to various stages of vitellogenesis, which drives how asynchronous the oocyte pattern appears (LOWERRE-BARBIERI et al. 2011).

Despite the absence of hydrated oocytes, the presence of POFs represents a subsequent phase. According to Brown-PETERSON et al. (2011), in warm-water batch spawners with indeterminate fecundity, oocytes in a batch normally undergo rapid OM and are released in a single spawning event. This author also reported that the late $\mathrm{OM}$ of $C$. nebulosus occurred within 10 hours in the natural environment in South Texas (Brown-PETERSEN et al. 1988). TAYLOR \& VILloso (1994) also described that C. regalis oocytes undergo late OM during the day with ovulation probably occurring between late afternoon and early evening. Therefore, the absence of hydrated oocytes could be circumstantial, and allows us to suppose that the oocytes of C. leiarchus undergo rapid OM and hydration, as other species of Cynoscion.

The presence of postovulatory follicles has been reported as evidence of recent spawning (VAzzoler 1996, Dias et al. 1998, MADDOCK \& BURTON 1999) since they remain in the ovary for less than 24 hours (Wilson \& NeILANd 1994, Lowerre-Barbieri et al. 2011). Our records on postovulatory follicles in this study suggest that the Sepetiba Bay might be used as reproductive grounds by at least part of the population of $C$. leiarchus. Furthermore, the occurrence of young-of-the-year of this species in great numbers at the nearshore waters of the bay was reported by Pessanha \& Araújo (2003) and Pereira et al. (2015). However, more studies are necessary to confirm this hypothesis.

Our findings indicate that C. leiarchus has higher relative fecundity than reported for C. guatucupa (292-649 oocytes $\times$ gram $^{-1}$ ) from the coast off the estuary of Rio da Prata (CASSIA 1986), but lower than populations off the coast of the state of Rio Grande do Sul (1,220-1,251 oocytes $\times$ gram $^{-1}$, VieIRA \& HaimoviCI 

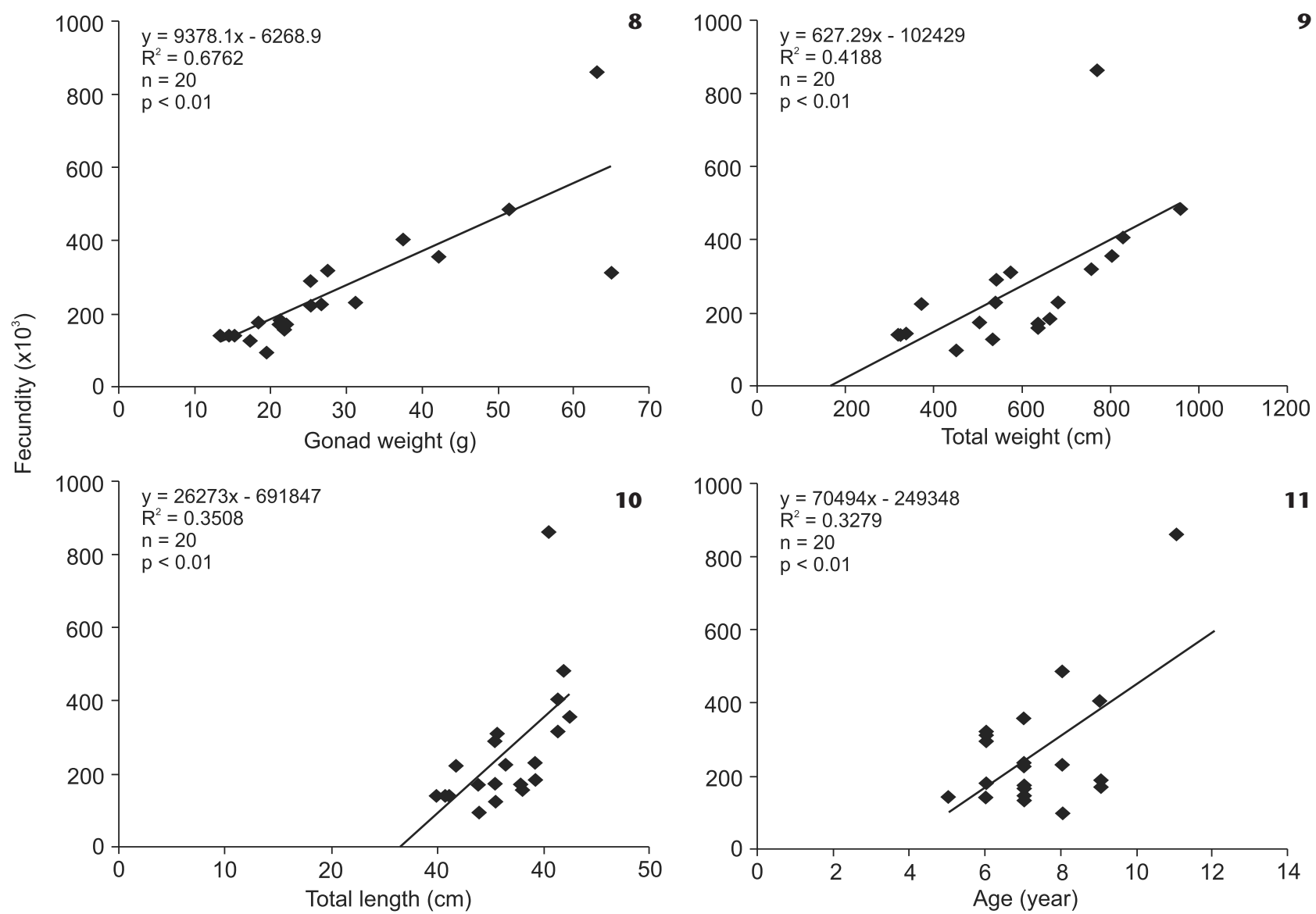

Figures 8-11. Relationship between batch fecundity and gonad weight (8), total weight (9), total length (10), and age (11) of Cynoscion leiarchus in Sepetiba Bay.

1997), results which are based on late oocyte maturation. This suggests that changes in fecundity are associated with different areas of the Argentinian-Uruguaian and Southern-Southeastern Brazilian coast and that this pattern in not consistent, as reported by Vieira \& Haimovici (1997). According to Brown-Peterson \& WARREN (2001), such changes are expected and are likely associated with differential environmental conditions or/and food availability.

In this study, gonadal weight was the best predictor of fecundity, compared with total length, body weight and age. This relationship is dependent of condition, in terms of absolute and relative body mass (Murua et al. 2003). Moreover, the direct relationship between length/age and fecundity suggests that older individuals are more fertile. Nevertheless, fecundity in teleosts could be affected by food availability, female condition, size and environmental conditions (MURUA \& Motos 2006, Dominguez-Petit \& Saborido-Rey 2010). Thus, for a given size, females in better condition exhibit higher fecundity (KJEsBu et al. 1991), indicating that size and condition are the key parameters to properly assess fecundity at the population level.
This study provides the first information on the gonadal development of $C$. leiarchus form the southeastern Brazilian bay. Similarly to other species from the Sciaenidae family, we confirm that the reproductive strategy is characterized by batch spawning, wide reproductive season and indeterminate fecundity. We believe that our findings contribute to clear and update the knowledge of gonadal development patterns and to provide a baseline for comparisons with other South American species of Cynoscion. As no information on these biological aspects currently exists in FishBase, the present results may also contribute to this database.

\section{ACKNOWLEDGEMENTS}

We thank Karina A. Keunecke, André M.V. dos Santos, Leonardo M. Neves and Petunia F. de Souza for all valuable contributions for this study. We also thank Armando Sales and the team of the Histological Techniques Laboratory staff for helping in histological techniques. This research was partially funded by Coordenação de Aperfeiçoamento de Pessoal de Nivel Superior (Proc. 23038.007371/2011) and Conselho Nacional de Desen- 
volvimento Científico e Tecnológico (Proc. 304954/2011-0). The Brazilian Institute for the Biodiversity Conservation provided the license for fish collecting (License 10.707) following the ethical procedures for handling animals.

\section{LITERATURE CITED}

Amarasekare P (2003) Competitive coexistence in spatially structured environments: a synthesis. Ecological Letters 6: 11091122. doi: 10.1046/j.1461-0248.2003.00530.x

Araújo FG, Azevedo MCC, Silva MA, Pessanha ALM, Gomes ID, Cruz-Filho AG (2002) Environmental influences on the demersal fish assemblages in the Sepetiba Bay, Brazil. Estuaries 25: 441-450. doi: 10.1007/BF02695986

Araújo FG, Guimarães FJC, Costa MR (2006) Environmental influences on distribution of four Sciaenidae species (Actinopterygii, Perciformes) in a tropical bay at Southeastern Brazil. Revista Brasileira de Zoologia 23: 497-508. doi: 10.1590/ S0101-81752006000200025

Armstrong MJ, Witthames PR (2012) Development in understanding of fecundity of fish stocks in relation to egg production methods for estimating spawning stock biomass. Fisheries Research 117-118: 35-47. doi: 10.1016/j.fishres.2010.12.028

BROWN-PETERSON NJ, WARREN JR (2001) The reproductive biology of spotted seatrout, Cynoscion nebulosus, along the Mississippi Gulf Coast. Gulf of Mexico Science 19: 61-73.

Brown-Peterson NJ, Thomas P, Arnolos CR (1988) Reproductive biology of the spotted seatrout, Cynoscion nebulosus, in south Texas. Fishery Bulletin 86: 373-388.

Brown-Peterson NJ, Peterson MS, Nieland DL, Murphy MD, Taylor RG, WARREN JR (2002) Reproductive biology of female spotted seatrout, Cynoscion nebulosus, in the Gulf of Mexico: differences among estuaries? Environmental Biology of Fishes 63: 405-415 doi: 10.1023/A:1014925421111

Brown-Peterson NJ, Wyanski DM, Saborido-Rey F, Macewicz BJ, LOWERRE-BARBIERI SK (2011) A standardized terminology for describing reproductive development in fishes. Marine and Coastal Fisheries: Dynamics, Management, and Ecosystem Science 3: 52-70. doi: 10.1080/19425120.2011.555724

Cassia MC (1986) Reproducción y fecundidad de la pescadilla de red (Cynoscion striatus). Publicaciones de la Comisión Técnica Mixta del Frente Marítimo 1: 191-203.

Chaves PTC (1989) Desenvolvimento dos ovócitos em Harengula clupeola, Urophycis brasiliensis, Eucinostomus argenteus, Isopisthus parvipinnis e Menthicirrhus americanus (Teleostei). Boletim Instituto Oceanografico de São Paulo 37: 81-93. doi: 10.1590/ S0373-55241989000200001

Chaves PTC, Vendel AN (1997) Reprodução de Stellifer rastriffer (Jordan) (Teleostei, Sciaenidae) na Baía de Guaratuba, Paraná, Brasil. Revista Brasileira de Zoologia 14: 81-89. doi: 10.1590/ S0101-81751997000100008

Costa, EFS, Dias JF, Murua H (2015) Reproductive strategy and fecundity of the keystone species Paralonchurus brasiliensis
(Teleoestei, Sciaenidae): an image processing techniques application. Environmental Biology of Fishes 96: 2093-2108. doi: 10.1080/17451000.2015.1136065

Costa, EFS, Dias JF, Murua H (2016) Fecundity of fishes inhabiting coastal and estuarine environments in the southwest Atlantic Ocean. Marine Biology Research 12: 304-315. doi: 10.1080/17451000.2015.1136065

Dias JF, Peres-Rio E, Chaves PTC, Rossi-Wongtschowski CLDB (1998) Analise macroscópica dos ovários de teleósteos: Problemas de classificação e recomendações de procedimentos. Revista Brasileira de Biologia 58: 55-69.

Dominguez-PetrT R, SAborido-Rey F (2010) New bioenergetic perspective of European hake (Merluccius merluccius L.) reproductive ecology. Fisheries Research 104: 83-88. doi: 10.1016/j.fishres.2009.09.002

Fonteles-Filho AA (2011) Oceanografia, biologia e dinâmica populacional de recursos pesqueiros. Fortaleza, Expressão Gráfica Editora, 464p.

Gherard KE, Erisman BE, Aburto-Oropeza O, Rowell K, Allen LG (2013) Growth, development, and reproduction in Gulf corvina (Cynoscion othonopterus). Bulletin Southern California Academy of Sciences 112: 1-18. doi: 10.3160/0038-3872-112.1.1

Gordo LS, Costa A, Abaunza P, Lucio P, Eltink ATGW, Figueiredo I (2008) Determinate versus indeterminate fecundity in horse mackerel. Fisheries Research 89: 181-185. doi: 10.1016/j. fishres.2007.09.024

Grier HJ, Uribe Aranzábal MC (2009) The testis and spermatogenesis in teleosts, p. 119-42. In: JAMIESON BGM (Ed.) Reproductive biology and phylogeny of fishes (Agnathans and Bony fishes). New Hampshire, Science Publishers.

Hunter JR, Macewicz BJ (1985) Measurement of spawning frequency in multiple spawning fishes, p. 79-94. In: LASKER $\mathrm{R}$ (Ed.) An egg production method for estimation spawning biomass of pelagic fish: application to the northen anchovy, Engraulis mordax. La Jolla, U.S. Department of Commerce, NOAA Technical Report NMFS36.

Hunter JR,Macewicz BJ, Lo NH, Kimbrell CA (1992). Fecundity, spawning, and maturity of female Dover sole Microstomus pacificus, with an evaluation of assumptions and precision. Fishery Bulletin 90: 101-128.

IBAMA (2008) Estatística da pesca 2006 Brasil: grandes regiões e unidades da federação. Brasília, Instituto Brasileiro do Meio Ambiente e dos Recursos Naturais Renováveis, 174p.

JALABERT B (2005) Particularities of reproduction and oogenesis in teleost fish compared to mammals. Reproduction, Nutrition and Development, EDP Sciences 45: 261-279.

Juras AA, Yamaguti N (1989) Sexual maturity, spawning and fecundity of king weakfish Macrodon ancylodon, caught of Rio Grande do Sul State (southern coast of Brazil). Boletim Instituto Oceanografico de São Paulo 37: 51-58. doi: 10.1590/S0373-55241989000100005

KJesbu OS, Klungsoyr J, Krivi H, Witthames PR, Greer Walker M (1991) Fecundity, atresia, and egg size of captive Atlantic (Gadus morhua) in relation to proximate body composition. 
Canadian Journal Fisheries and Aquatic Science 48: 23332343. doi: 10.1139/f91-274

Lambert Y, Yaragina NA, Kraus G, Marteinsdottir G, Wright PJ (2003) Using environmental and biological indices as proxies for egg and larval production of marine fish. Journal of Northwest Atlantic Fishery Science 33: 115-159. doi: 10.2960/J.v33.a7

LOWERRE-BARBIERI SK (2009) Reproduction in relation to conservation and exploitation of marine fishes, p. 94. In: JAMIESON BGM (Ed.). Reproductive Biology and Phylogeny of Fishes (Agnathans and Bony Fishes). Durham, CRC Press.

Lowerre-Barbieri S.K, Ganias K, Saborido-Rey F, Murua H, Hunter JR (2011) Reproductive timing in marine fishes: variability, temporal scales, and methods. Marine and Coastal Fisheries: Dynamics, Management, and Ecosystem Science 3: 71-91. doi: 10.1080/19425120.2011.556932

Maddock DM, BurTon MPM (1999) Gross and histological observations of ovarian development and related condition changes in American plaice. Journal of Fish Biology 53: 928-944. doi: 10.1111/j.1095-8649.1998.tb00454.x

Marcano L, Alió J (2001) Reproductive aspects of the jamaica weakfish, Cynoscion jamaicensis in the northern coast of Paria Peninsula, Sucre state, Venezuela. Zootecnia Tropical 19: 371-392.

Menezes NA, Figueiredo JL (1980) Manual de Peixes Marinhos do Sudeste do Brasil. IV. Teleostei (3). São Paulo, Museu de Zoologia, Universidade de São Paulo, 96p.

Militelli MI, Macchi GJ (2006) Spawning and fecundity of striped weakfish, Cynoscion guatucupa, in the Rio de la Plata estuary and adjacent marine waters, Argentina-Uruguay. Fisheries Research 77: 110-114. doi: 10.1016/j.fishres.2005.08.004

MPA (2012) Boletim estatístico da pesca e aquicultura, Brasil 2011. Brasília, Ministério da Pesca e Aquicultura, available online at: http://www.icmbio.gov.br/cepsul/images/stories/ biblioteca/download/estatistica/est_2011_bol_bra.pdf [Accessed: 29/09/2016]

Murua H, SABorido-Rey F (2003) Female reproductive strategies of marine fish species of the North Atlantic. Journal of Northwest Atlantic Fisheries Science 33: 23-31. doi: 10.2960/J.v33.a2

Murua H, Motos L (2006) Reproductive strategy and spawning activity of the European hake Merluccius merllucius (L.) in the Bay of Biscay. Journal of Fish Biology 69: 1288-1303. doi: 10.1111/j.1095-8649.2006.01169.x

Murua H, Kraus G, Saborido-Rey F, Witthames PR, Thorsen A, Junguera S (2003) Procedures to estimate fecundity of marine fish species in relation to their reproductive strategies. Journal of Northwest Atlantic Fisheries Science 33: 33-54. doi: 10.2960/J.v33.a3

Pessanha ALM, Araújo FG (2003) Spatial, temporal and diel variations of fish assemblages at two sandy beaches in the Sepetiba Bay, Rio de Janeiro, Brazil. Estuarine Coastal and Shelf Science 57: 817-828. doi: 10.1016/S0272-7714(02)00411-0

Pereira HH, Neves LM, Costa MR, Araújo FG (2015) Fish assemblage structure on sandy beaches with different anthropogenic influences and proximity of spawning grounds. Marine Ecology 36: 16-27 doi: 10.1111/maec.12113
PIANKA ER (1970) On r-and K-selection. American Naturalist 104: 592-597.

Roof DA (1992) The evolution of life histories: Theory and analysis. New York, Chapman and Hall, 535p.

Roumillat WA, Brouwer MC (2004) Reproductive dynamics of female spotted seatrout (Cynoscion nebulosus) in South Carolina. Fishery Bulletin 102: 473-487.

Selman K, Wallace RA (1989) Cellular aspects of oocyte growth in teleosts. Zoological Science 6: 211-231.

Spector DL, Goldman RD (2006) Basic methods in microscopy. Chicago, University Medical School, 382p.

SILVA JPC (2015) Biologia reprodutiva, idade e crescimento da pescada branca Cynoscion leiarchus (Actinopterygii, Sciaenidae) na Baía de Sepetiba, RJ. Seropédica, Dissertação Mestrado, Universidade Federal Rural do Rio de Janeiro, 89p. Available online at: http://www.ufrrj.br/posgrad/cpgba/teses/ Dissertacao_JOSE\%20PAULO\%20do\%20Carmo\%20Silva.pdf

TAYLOR MH, VILLOSO EP (1994) Daily ovarian and spawing cycles in weakfish. Transactions of American Fisheries Society 123: 9-14. doi: 10.1577/1548-8659(1994)123<0009:DOASCI>2.3.CO;2

VAzzoLER AEAM (1996) Biologia da reprodução de peixes teleósteos: teoria e prática. Maringá, EDUEM, 169p.

Vieira PJC, Haimovici M (1997) Reprodução da pescada olhuda Cynoscion guatucupa, sin C. striatus (Sciaenidae, Teleostei) no Sul do Brasil. Atlântica 19: 133-144.

Wallace RA, Selman K (1981) Cellular and dynamic aspects of oocyte growth in teleosts. American Zoologist 21: 325-343. doi: $10.1093 / \mathrm{icb} / 21.2 .325$

WiLSON CA, NiELAND DL (1994) Reproductive biology of red drum, Sciaenops ocellatus, from the neritic waters of the northern Gulf of Mexico. Fishery Bulletin 92: 841-850.

Winemiller KO, Layman CA (2005) Food web science: Moving on the path from abstraction to prediction, p. 10-23. In: DE Rutter PC, Wolters V, Moore JC (Eds) Dynamic food webs: Multispecies assemblages, ecosystem development and environmental change. Amsterdam, Elsevier, 608p.

WootTon RJ (1984) Introduction: strategies and tactics in fish reproduction, p. 1-12. In: PотTs GW, Wоotтon RJ (Eds.) Fish reproduction: strategies and tatics. London, Academic Press. WootTon RJ (1992) Fish ecology. London, Chapman and Hall, 212p.

\section{Submitted: 21 February, 2016}

Received in revised form: 3 June, 2016

Accepted: 4 July, 2016

Editorial responsibility: Cassiano Monteiro Neto

Author Contributions: JPCS and FGA designed the experiments; JPCS, IDG and FGA conducted the experiments; JPCS, MRC and FGA analyzed the data; JPCS, MRC, IDG and FGA wrote the paper.

Competing Interests: The authors have declared that no competing interests exist. 